\title{
Understanding the Dynamics of Sport-Career Transition of Olympic Athletes
}

\author{
Prof J Surujlal
}

North-West University (Vaal Triangle Campus) Faculty of Economic Sciences and Information Technology Email: Babs.Surujlal@nwu.ac.za

Dr Y van Zyl

Vaal University of Technology, Faculty of Management Sciences, Department of Human Resource Management Email: yolandivz@vut.ac.za

\author{
Doi:10.5901/mjss.2014.v5n20p477
}

\begin{abstract}
Transition from elite sport to the mainstream society may be a traumatic experience for the elite athlete. The purpose of this study was to gain an understanding and insight into the dynamics of the sport-career transition from the perspective of former Olympic athletes. A comprehensive literature study on sport-career transition was conducted. A qualitative approach was used to gather data from two retired Olympic athletes. Scheduled interviews with the athletes were conducted, recorded with their permission and transcribed. The interview was divided into three main sections, namely family background and life before competitive sports, life during competition and training for the Olympic Games, and life after sport and the transition to the workplace. The recorded data was converted to meaningful aspects through content analysis. The results indicate that athletes developed life skills through their participation in athletics, which they transferred to their current jobs. Both athletes indicated that they did not receive any form of retirement counselling or followed a programme in assisting them with the transition from being an elite athlete to following a different career path. It is recommended that sport-governing bodies assist athletes in planning their careers before their transition to mainstream society.
\end{abstract}

Keywords: Olympic athletes, career transition, support, dynamics

\section{Introduction}

Since the early 1980s, the area of sport-career transition has gained increased attention in the sport psychology literature (Coakley, 2006). Schlossberg (1981, p. 5) describes a transition as "an event or non-event which results in a change in assumptions about oneself and the world and thus requires a corresponding change in one's behaviour and relationships". Cecić Erpič (2003) posits that while the onset of a transition may be linked to one identifiable event (in this study transition from elite sport), transitions are a process that are influenced by four major sets of factors, namely situation, self, support, and strategies. In addition, Schlossberg, Waters and Goodman (1995) suggest that there are three components in the transition process, namely approaching transition, taking stock of coping resources (inter alia physical and psychological resources to cope with the transition), and taking charge of transition (inter alia being able to take control of the process). The current study focuses on the last component. This stage requires an athlete to adapt to post-sports life on a psychological, social, physical, and socio-economic level (Cecić Erpič, 2002), thereby imposing a set of specific demands requiring adjustment by him/her. Alfermann (2000) suggests that instead of focusing on the difficulties and trauma associated with transition out of elite sports, one should rather view the transition as a life event, which influences an athlete's future well-being and development.

According to Coakley (2006), the sport-career transition is a complex, multidimensional process and the outcome is contingent upon the individuals' cognitive, social, behavioural and emotional resources and level of preparation for the sport-career transition. Transition from elite sport is an inevitable event in the lives of elite athletes. It may be abrupt resulting from a career-ending injury, chronological age, reduced performance levels or de-selection (Maseko \& Surujlal, 2011) or planned, expected or a personal choice (Lavallee \& Wylleman, 2000). For those who have not planned the event there may be negative repercussions such as identity crisis reactions (Brewer, Van Raalte \& Petitpas, 2000), emotional difficulties (Allison \& Meyer, 1988) and possibly decreased self-confidence and life satisfaction (Werthner \& Orlick, 1986) 
due to changes in social and professional life. Some may find the transition a smooth and positive experience. A positive transition takes place when the athlete makes a quick and easy adjustment to the demands of the transition (Coakley, 2006). Despite this, it is still likely that athletes would miss the pressure, stress, discipline and routine associated with participation in elite sport (Chamalidis, 2000). Athletes may experience bodily changes, which may be as a result of increased weight, lack of fitness, decreased physical prowess that may ultimately contribute to higher levels of stress and anxiety (Drahota \& Eitzen, 1998). Brandao, Winterstein, Pinheiro, Agresta, Akel and Martini (2001) and Stambulova (1994) postulated that the average time to transit out of elite sport, to life outside elite sport, is between six months to one year; a time during which re-orientation and adjustment to a new lifestyle takes place.

Wylleman, Lavallee and Alfermann (1999) suggest difficulties usually experienced during transition may be overcome by pre-retirement planning of post-sports life. This suggestion corroborates Pearson and Petitpas' (1990) view that pre-retirement planning of post-sports life influences the quality of adaptation to life following a competitive sports career to a large extent. Despite the fact that there is empirical evidence (Stambulova, 1994) to suggest that a relationship exists between post-sports life planning and a less difficult adaptation to post-sports life, Cecić Erpič, Wylleman and Zupančič (2004) found empirically supported evidence that approximately 26 percent of athletes do not plan their life after active sports involvement.

\section{Elite Athletes' Transition Out of Sport}

Anecdotal evidence suggests that transition out of elite sport is often not a pleasant experience for successful athletes who have become accustomed to being in the limelight, receiving accolades and being in the company of high profile individuals. Taylor and Ogilvie (1998) assert that an athlete's commitment to sports and the consequent reduction of time and energy spent in other social roles (for example student, partner, friend, community member) often leads to the formation of a strong athletic identity, which is related to risk for experiencing difficulties after sport career transition. Cecić Erpič (2002) concurs with the aforementioned assertion adding that while an athlete's commitment to sports can have a positive influence on sports achievements, exercise adherence and athletic performance, a strong athletic identity may lead him/her to experience difficulties after sport career termination. Athletes who develop a strong athletic identity may be prone to more severe and frequent psychological difficulties as well as with more difficulties in organising their post-sports career life (Cecić Erpič et al., 2004).

Sport career transition is an important life event for elite athletes, which has to be coped with. In their assessment of various empirical studies, Cecić Erpič et al. (2004) found that retiring athletes often face difficulties on psychological, physical, psychosocial and socio-economic levels. On a psychological level, difficulties athletes faced are associated with identity crisis, loss of self-worth, low self-esteem and substance abuse while on a physical level injuries, health problems and difficulties with detraining are difficulties experienced (Cecić Erpič et al., 2004). On a psychosocial level, athletes become prone to social loneliness and problems in engaging in new non sport-related relationships. Athletes may also, on a socio-economic level experience absence of a professional career and possibly a drop in financial income (Wylleman, Lavallee \& Alfermann, 1999).

Anderson and Morris (2000) suggest that because of the joy, identity and love which athletes experience through participation in sport, the thought of leaving it becomes emotionally distressing. Because sport has become a way of life (Stephan, Bilard, Ninot \& Delignieres, 2002) de-socialisation from sport may become difficult for athletes. This may result in negative beliefs regarding a sport career and post-sport life (Mateos, Torregrosa, \& Cruz, 2010).

\section{Problem Statement}

Transition from elite sports (voluntary or not) requires athletes to cope with a new lifestyle on a social, physical and personal level. Grove, Lavallee, Gordon and Harvey (1998) posit that athletes require considerable emotional adjustment to life outside elite sport. While earlier research (Mihovilović, 1968; Werthner \& Orlick, 1986) suggested that transition from sport to real life is a traumatic and difficult experience, more recent studies (Coakley, 2006; Wylleman et al., 1999,) have found that only a minority of athletes face serious difficulties during sport career transition.

Participation in elite sport requires athletes to be exceptionally fit, both physically as well as psychologically. In their quest for excellence, athletes are required to develop high levels of determination, persistence and patience to reach their potential (Barker-Ruchti, Barker, Lee \& Rynne, 2011). If athletes are able to develop such characteristics, one may assume that they would be able to cope and succeed in life beyond sport. Barker-Ruchti et al. (2011), however, argue that this is not always the case. The authors opine that while some elite athletes transit painlessly into new domains, others encounter difficulties adapting to different lives with many experiencing forms of disorientation, depression and 
self-doubt. The transition of athletes has received increased research interest by sport psychologists (Conzelmann \& Nagel, 2003). Little evidence exists in a South African context regarding the adjustment experiences of Olympic athletes who transit from elite sports. It is envisaged that the findings of this study would contribute to the existing literature on transition in sport and provide information to prepare guidelines to assist athletes to transit smoothly from sport into mainstream life. Mainstream life in the context of this study refers to life outside competitive sport.

\section{Purpose of Study}

The primary purpose of this study is to gain an understanding and insight into the dynamics of the sport-career transition from the perspective of former Olympic athletes.

\section{Methodology}

A case study approach was deemed appropriate for the current study. A case study is an intensive study of a specific individual or specific context (Trochim, 2006). Hitchcock and Hughes (1995) regard a case study as study of key players, key situations and critical incidents in life. According to Nunan (1992), it is the investigation of a single phenomenon in the context in which it occurs. In this study, the key players are the retired Olympic athletes, the key situations and critical incidents are associated with participation in elite sport, and the phenomenon is their transition to the workplace.

A qualitative research approach utilising semi-structured in depth interviews was used for the study. Qualitative methodologies are ideal for use in understanding the individual's subjective experience regarding a particular phenomenon. The goal is to provide evidence in the form of accounts individuals share about their experiences (Polkinghorne, 2005). In this approach, research is carried out in real-life situations (Nieuwenhuis, 2007) with the purpose of gaining new data and revealing many experiences of the people who are met by the researcher. Gaining insight into the worlds of the participants assists the interviewer in reconstructing events regarding the phenomenon being researched (Fox \& Bayat, 2007).

\subsection{Sample}

The sample in this study comprised two retired male South African athletes who competed in the Olympics. Participant 1 was a member of the national team from 1999 to 2008 and Participant 2 from 2002 to 2008; both athletes retired in 2008.

\subsection{Instrument and Procedures}

Ungerleider's (1997) three categories for transition from sport to workplace were used as the basis to develop an interview schedule. The interview schedule was divided into three sections, namely family background and life before competitive sports, life during competition and training for the Olympic Games and life after sport with the transition to the workplace. Sofaer (2002:334) posits that an interview schedule is the "hallmark of a qualitative interview". It encourages participants to reflect in detail on experienced events and allows flexibility during the interview (Moerdyk, 2009; Nieuwenhuis, 2007; Fox \& Bayat, 2007; Rule \& Vaughn, 2011).

Prior to the interviews, the purpose of the study was explained to the participants and they were requested to participate in the study. Both participants indicated their willingness to take part in the research project. Interview dates and times were scheduled to suit the participants. Both interviews took place at the participants' respective homes. Before commencement of the interviews, participants' were assured of confidentiality and anonymity and were informed that participation was voluntary, and that they may withdraw at any point during the interview process.

Permission was requested from each participant to record the interview. The same researcher conducted both interviews. Field notes were taken during the interview for "initial interpretations of what was heard" (Leedy \& Ormrod, 2005:143). Principal researcher transcribed recordings of the interviews, which were analysed independently by the researchers.

\subsection{Data Analysis}

Content analysis was used in analysing the data. It is a method where the content of the data forms the basis for drawing inferences and conclusions about the content (Nachimias \& Nachimias, 1981). The goal of content analysis was to convert recorded raw data into clear and meaningful aspects, which can be treated in a scientific manner so that a body 
of knowledge maybe built up. Both researchers examining the transcripts independently in conjunction with the recordings did this. After both researchers analysed the data, their findings were compared and where differences occurred, a discussion ensued until consensus regarding the interpretation of the data was reached.

\section{Results}

For the sake of anonymity, the participants are named John (Participant 1) and the other Jack (Participant 2). Both participants were very forthcoming with regard to their transition from elite sport to mainstream society. General information on family background and life before competitive sport is provided in Table 1.

Table 1. Family background and life before competitive sport

\begin{tabular}{|l|l|l|}
\hline \multicolumn{1}{|c|}{ Aspect } & \multicolumn{1}{|c|}{ John (Participant 1) } & Jack (Participant 2) \\
\hline Sport & Athletics & Athletics \\
\hline Family members participating in sport & Both parents & None \\
\hline Sporting influence & Love for sport & Love for sport \\
\hline Entry level to sport & Television coverage of sport & Primary school \\
\hline Participation in competitive sport & 18 years old & 1st year of university \\
\hline First Olympic appearance & 19 years old & 23 years old \\
\hline Coach & Independent coach Supportive coaching provided by father & Independent coach \\
\hline
\end{tabular}

The participants competed in athletics and they did so at the highest level - the Olympics. Both of John's parents participated in athletics. However, this was during the apartheid era when South Africans were not allowed to participate internationally. None of Jack's family members were involved in any sport. Both participants indicated that they were not influenced by any other individual to participate in sport but rather they showed a keen interest because of their love for sport. John also indicated that his following athletics on television played a huge role in him choosing an athletic career. Both participated in various sports from a very young age at primary school. They only realised that they had the potential to perform competitively at a high level when John had just finished school and Jack was a first year university student.

John had his first taste of Olympic competition at the age of 19 years, while Jack participated for the first time in the Olympics at the age of 23 years. While both participants had their own individual coaches; his father also supported John's coaching.

\subsection{The Olympic Experience}

When requested to describe their olympic experience both participants related similar experiences. John described it as "indescribable" with a "feeling and atmosphere that you will not find in any other event" while Jack described it as "everything was bigger and better". For Jack the experience was a "life changing" one with him having to adapt to a new lifestyle. He found the Olympic Games to be more "intense and demanding" than other games such as the Winter Games and Commonwealth Games. John, on the other hand, found that the Olympic experience blended with his lifestyle reporting that the Olympic experience provided him with the opportunity to "train harder and smarter". It inculcated discipline, hard work and focus in him.

\subsection{Support}

In terms of support, both participants indicated that they enjoyed support from family and friends. Jack described the support he received as "unbelievable" and "amazing". In many instances, people he did not even know came forward to offer him support. John, on the other hand, enjoyed support mainly from his family who were all sport lovers.

\subsection{Negative experiences}

Although there was always the glamour and limelight that the athletes enjoyed, they also had negative experiences associated with the Olympics. For Jack the most negative experience was underperforming and not qualifying for an event. John's most negative experience was an injury, which almost resulted in him not participating in the 2004 Athens 
Olympics. However, "technological advancements in medicine" ensured his quick rehabilitation and participation.

\subsection{Positive experiences}

Jack's most positive experience was "stepping on the track for the first time" and realising that he was participating in the Olympics. For John the opening ceremony at the Sydney Olympics was a "positively emotional experience" and "a dream come true". He could not believe he was a participant. For John merely participating was a positive experience.

\subsection{Pressure}

Jack experienced very little pressure in lesser competitions. However, his qualifying and participating in the Olympics brought along increased pressure. He realised that he was no longer representing his club but his country. Not only was he preparing and training for his athletic event, he also had to be prepared for radio as well as television interviews. While previously he exerted pressure on himself, he now experienced pressure from his coach as well as family and friends. John also experienced pressure on a personal as well as professional level. The feeling of "millions of people watching you" was a huge source of pressure for him.

\subsection{Transition to mainstream society}

Both athletes reported different experiences regarding their transition to mainstream society. For John the transition to mainstream society was an easy one. He indicated that he approached his retirement from athletics "realistically" and "felt when it was time to retire" and "move on to the next chapter" of his life. When asked whether he had a programme to assist him in his transition he responded that he did not need it. He personally made the decision to retire from professional competition and he was "sure" of his decision. He had to make a few "adjustments"; the adjustment that he had to make was not emotional or psychological rather, it was physical. Given his new lifestyle, which required him to work from "eight to five", as well as being a parent, he found it extremely difficult to stick to a rigid training schedule to keep fit. Without the discipline associated with training, he was also not able to stick to a nutrition plan. Participating at Olympic level honed many of John's life skills, which made his transition to mainstream society easier. Among the life skills he developed during the course of his professional athletics career were patience, focus, goal-orientation, dedication, self-discipline and tolerance all of which are implemented in his current career in the corporate world.

Some of Jack's experiences of transition into mainstream society were similar to those of John's, in that he also does not follow a rigid and disciplined nutrition and training programme. He describes his life with regard to training as "nothing is cast in stone anymore". He also did not have a programme or counselling to facilitate his transition to mainstream society. Jack indicated that he is still "adjusting" both "emotionally and physically" to mainstream society. He described a feeling of still being "stuck" in the athletics world. He is still experiencing difficulty in adjusting to his strict working hours, lack of travelling and lack of free time. Among the life skills he developed during his athletics career were people skills, which helped him to relate easily to people. Dedication, perseverance and meeting deadlines were also skills, which were developed that help him in his current job. Unlike John whose decision to retire was a personal one, the athletics federation largely played an influential role in "forcing" Jack to retire.

\section{Discussion}

It is interesting to note that both participants competed in various sports at a young age in primary school. According to Balyi, Way and Higgs' (2013) long term athletic development model (LTAD) athletes develop through a variety of wellstructured activities with a focus on fun at an early age. In keeping with the LTAD model, the participants in the study only began to train to compete after the age of 16 years.

Both athletes had a support network while competing professionally, consisting of family, friends, coaches and team mates. McKnight, Bernes, Gunn, Chorney, Orr and Bardick (2009) argue that transitioning athletes may feel isolated from their former social support network such as their coach and team. Outside sport, they need to reconnect or create new support networks. In this regard transitioning athletes can benefit a great deal from ongoing social support from their sport federations.

One of the participants found it difficult to adjust to mainstream society and a plausible reason for the emotional distress that he experienced in adjusting could be that with the passage of time his source of joy, identity and love was his sport (Anderson \& Morris, 2000). Furthermore, his lifestyle was influenced by his sport and this impacted negatively 
on his transition (Bilard, Ninot \& Delignieres, 2002). Taylor and Ogilvie (1998) posit that athletes who have been immersed in sport activities to the exclusion of activities outside sport develop a self-identity associated with sport and this poses a serious barrier to a smooth transition. This resonates with Lavallee, Gordon and Grove's (1997:137) assertion that "individuals with a high athletic identity at the time of retirement experience a higher degree of emotional adjustment difficulties".

The transition experiences of both participants differed with one having a positive transition and the other experiencing a negative transition. According to Coakley (2006) a positive transition occurs when an athlete makes a relatively quick and easy adjustment to life outside sport. The authors however posit that this is only possible if the precondition of planning for the transition is met during the athletic career. This, therefore, explains why John, who planned his retirement from elite sport found it easier to transit than Jack who did not plan his transition. According to Alfermann, Stambulova and Zemaityte (2004) planned retirement is associated with more positive and less negative emotional reactions to retirement from sport, shorter duration of the transitional period, lesser use of distraction strategies and higher current life satisfaction. This implies that athletes who plan their retirement in advance, expend less energy in adjusting to their new lifestyles and hence are able to mobilise and use their resources more effectively than athletes who do not plan their retirement.

With reference to maintaining their level of fitness and sticking to a rigid nutrition plan, both participants went through a period of physical adjustment, finding it difficult in not training that often anymore and in following a healthconscious diet. One of the participants is still adjusting physically and missing the commitment to compete professionally. Stephan, Bilard, Ninot, and Delignieres, (2003:202) state that "because of the centrality of the physical self in identity and feelings of self-worth during the sport career, transition from a bodily over-investment to a more sedentary state is marked by a loss of physical efficiency that is detrimental to perceptions of both competencies and global self-esteem. This stressful period is followed by a period of adjustment to new physical capacities and a re-evaluation of self-perceptions".

Both participants developed skills, which they could transfer to their current jobs. Coakley (2006) posits that many transferable skills developed during one's athletic career contribute positively to future jobs that one may have. In similar vein, Westerbeek and Smith (2005) suggested that elite sport involvement creates the potential for skill exchange between sport and business, thereby easing the transition from elite sport to a non-sport environment. Smith and McManus (2008) also asserted that upon retirement, athletes should be equipped with a balanced and diverse range of life competencies to enable a smooth transition personally, socially, professionally/academically and financially into postsport life. They also need to be aware of the value of their skills and how their skills can be transferred to areas outside sport (McKnight et al., 2009)

\section{Recommendations}

Arising from the findings of the study are a few recommendations. In view of the fact that both athletes did not receive any retirement counselling, it is recommended that sport-governing bodies include a compulsory counselling programme to facilitate the retirement of athletes from elite sport. This should be done early in the athlete's career so that the athlete can continuously prepare for that period of his/her life. This can be implemented in the form of mini workshops conducted by professionals. Prior to retired athletes leaving the sport organisation, managers should engage in an exit interview with the athlete to determine his/her preparedness for retirement. This information would help in preparing subsequent athletes for retirement.

It is also recommended that sport-governing bodies assist athletes in planning their careers after elite sport. At the very outset, they should be alerted to the fact that sport is a short-term career (Ungerleider, 1997). While the two participants in this study transited into other careers because they were linked to a university early in their careers, some aspiring athletes may participate in elite competition at an earlier age and may not have the opportunity to pursue any academic programmes to prepare them for a career after elite competition. It is therefore recommended that in addition to career guidance being provided for them, they be guided towards some form of training or academic programme which will assist them in finding employment after their athletic careers. In this regard, McKnight et al. (2009) propose that counsellors may be effective in assisting athletes to engage in life after sport by helping them learn skills they need to be successful in other areas of their life besides sport.

\section{Conclusion}

The purpose of this study was to gain an understanding and insight into the dynamics of the sport-career transition from former Olympic athletes' perspective. Transition from elite sport into mainstream society may be difficult and disruptive. 
Numerous factors could possibly contribute to the retirement of athletes from elite sport and athletes therefore need to prepare adequately for this period of their lives. In this regard, sport governing bodies and sport coaches have key roles to play.

\section{References}

Alfermann, D. (2000). Causes and consequences of sport career termination. In D. Lavallee and P. Wylleman (Eds.) Career transitions in sport: international perspective (pp. 45-58). Morgantown: Fitness Information Technology.

Alfermann, D., Stambulova, N., \& Zemaityte, A. (2004). Reactions to sport career termination: a cross-national comparison of German, Lithuanian, and Russian athletes. Psychology of Sport and Exercise, 5, 61-75.

Allison, M. T., \& Meyer, C. (1988). Career problems and retirement among elite athletes: the female tennis professional. Sociology of Sport Journal, 5, 212-222.

Anderson, D., \& Morris, T. (2000). Athlete lifestyle problems. In D. Lavallee \& P. Wylleman, (Eds.) Career transitions in sport: international perspectives (pp. 59-80). Morgantown, WV.: Fitness Information Technology.

Balyi, I., Way, R., \& Higgs, C. (2013). Long-term athlete development. [Online] Available: http://www.humankinetics.com/products/allproducts/long-term-athlete-development (April 21, 2014).

Barker-Ruchti, N., Barker, D., Lee, J., \& Rynne, S. (2011). Preparing Olympic athletes for lives outside of elite sport: towards best practice. IOC Postgraduate Research Grant 2011 - Final report. Sweden: University of Gothenburg.

Bilard, S. Y., Ninot, J., \& Delignieres, D. (2002). Repercussions of transition out of elite sport on subjective well-being: a one year study. Journal of Applied Sport Psychology, 15, 354-371.

Brandao, M. R. F., Winterstein, P., Pinheiro, .C, Agresta, M., Akel, M. C. \& Martini, L. (2001). Career transition of former Brazilian top level athletes. In A.Papaioannou, M. Goudas \& Y. Theodorakis (Eds) 10th World Congress of Sport Psychology (pp. 1-2). Skiatos: International Society of Sports Psychology.

Brewer, B. W., Van Raalte, J. L., \& Petitpas, A. J. (2000). Self-identity issues in sport career transitions. In D. Lavallee, \& P. Wylleman (Eds.) Career transitions in sport: international perspective (pp. 29-43). Morgantown: Fitness Information Technology.

Cecić Erpič, S. (2002). Sports career termination: developmental- and sport- psychological aspects. Slovenia: University of Ljubljana, Faculty of Sports, Ljubljana. .

Cecić Erpič, S. (2003). Sports career transition phase: an entity or a sum of sub-phases? In XIth European Congress of Sport Psychology, Copenhagen: Collection of articles (p. 4). Copenhagen: FEPSAC. Cecić Erpič, S., Wylleman, P., \& Zupančič, M. (2004). The effect of athletic and non-athletic factors on the sports career termination process. Psychology of Sport and Exercise, 5(1), 45-59.

Chamalidis, P. (2000). Shines and miseries of champions. Montreal: VLB.

Coakley, S. C. (2006). A phenomenological exploration of the sport-career transition experiences that affect subjective well-being of former National Football League players. [Online] Available: http://libres.uncg.edu/ir/uncg/f/umi-uncg-1099.pdf (February 02, 2014).

Conzelmann, A., \& Nagel, S. (2003). Professional careers of German Olympic athletes. International Review for the Sociology of Sport, 38(3), 259-280.

Drahota, J. T., \& Eitzen, D. S. (1998). The role exit of professional athletes. Sociology of Sport Journal, 15, 263-278.

Fox, W., \& Bayat, M. S. (2007). A Guide to Managing Research. Cape Town: Juta.

Grove, J. R., Lavallee, D., Gordon, S., \& Harvey, J. H. (1998). Account-making: a model for understanding and resolving distressful reactions to retirement from sport. The Sport Psychologist, 12, 52-67.

Hitchcock, G., \& Hughes, D. (1995). Research and the Teacher (2nd ed.). London: Routledge.

Lavallee, D., Gordon, S., \& Grove, J. R. (1997). Retirement from sport and the loss of athletic identity. Journal of Personal and Interpersonal Loss: International Perspectives on Stress \& Coping, 2(2), 129-147.

Lavallee, D., \& Wylleman, P. (2000). Career transitions in sport: international perspectives. Morgantown, WV: Fitness Information Technology.

Leedy, P. D., \& Ormrod, J. E. (2005). Practical research. Planning and design (8th ed.). New Jersey: Pearson Prentice Hall.

Maseko, J., \& Surujlal, J. (2011). Retirement planning among South African professional soccer players: A qualitative study of players' perceptions. African Journal for Physical, Health Education, Recreation and Dance (AJPHERD), Special Edition, September (Supplement), 157-171.

Mateos, M., Torregrosa, M., \& Cruz, J. (2010). Evaluation of a career assistance programme for elite athletes: satisfaction levels and exploration of career decision making and athletic-identity. Kinesiologia Slovenica, 16(2), 30-43.

McKnight, K., Bernes, K., Gunn, T., Chorney, D., Orr, D., \& Bardick, A. (2009). Life after sport: athletic career transition and transferable skills. Journal of Excellence, 13, 63-77.

Mihovilović, M. (1968). The status of former sportsmen. International Review of Sport Sociology, 3, 73-93.

Moerdyk, A. (2009). The principles and practice of psychological assessment. Pretoria: Van Schaik Publishers.

Nachimias, D., \& Nachimias, C. (1981). Research methods in the social sciences. (2nd ed.). New York: St. Martin's Press.

Nieuwenhuis, J. (2007). Introducing qualitative research. In K. Maree (Eds.) First steps in research (pp. 46-68). Pretoria: Van Schaik Publishers.

Nunan, D. (1992). Research methods in language learning. Cambridge University Press: Cambridge. 
Pearson, R., \& Petitpas, A. (1990). Transition of athletes: pitfalls and prevention. Journal of Counseling and Development, 69, 7-10.

Polkinghorne, D. E. (2005). Language and meaning: data collection in qualitative research. Journal of Counseling Psychology, 52(2), 137-145.

Rule, P., \& Vaughn, J. (2011). Your guide to case study research. Pretoria: Van Schaik Publishers.

Schlossberg, N. K. (1981). A model for analysing human adaptation to transition. The Counseling Psychologist, 9(2), 2-18.

Schlossberg, N. K., Waters, E. B., \& Goodman, J. (1995). Counseling adults in transition: linking practice with theory. New York: Springer.

Smith, J. L., \& McManus, A. (2008). A review on transitional implications for retiring elite athletes: What happens when the spotlight dims? The Open Sports Sciences Journal, 1, 45-49.

Sofaer, S. (2002). Qualitative research methods. International Journal for Quality in Health Care, 14(4), 329-336.

Stambulova, N. B. (1994). Developmental sports career investigations in Russia. A post-perestroika analysis. The Sport Psychologist, 8 , 221-237.

Stephan, Y., Bilard, J., Ninot, G., \& Delignieres, D. (2002). Repercussions of transition out of elite sport on subjective well-being: a one year study. Journal of Applied Sport Psychology, 15, 354-371.

Stephan, Y., Bilard, J., Ninot, G., \& Delignieres, D. (2003). Bodily transition out of elite sport: a one-year study of physical self and global self-esteem among transitional athletes. International Journal of Sport Psychology, 1(2), 192-207.

Taylor, J., \& Ogilvie, B. C. (1998). Career transition among elite athletes: Is there life after sports? In J. M. Williams (Ed.), Applied Sport Psychology: Personal Growth to Peak Performance (pp. 429-444). Mountain View: Mayfield.

Trochim.W. M. K. (2006). Qualitative methods. [Online] Available: http://www.socialresearchmethods.net/kb/qualmeth.php (March 21, 2014).

Ungerleider, S. (1997). Olympic athletes' transition from sport to workplace. Perceptual and Motor Skills, 84, 1287-1295.

Werthner, P., \& Orlick, T. (1986). Retirement experiences of successful Olympic athletes. International Journal of Sport Psychology, 17, 337-363.

Westerbeek, H., \& Smith, A. (2005). Business leadership and the lessons from sport. Basingstoke: Palgrave Macmillan.

Wylleman, P., Lavallee, D., \& Alfermann, D. (1999). Career transitions in competitive sports. Biel: FEPSAC. 